\title{
Reduction of Nitric Oxide with Hydrogen on Catalysts of Singly Dispersed Bimetallic Sites $\mathrm{Pt}_{1} \mathrm{Co}_{\mathrm{m}}$ and $\mathrm{Pd}_{1} \mathrm{Co}_{\mathrm{n}}$
}

\author{
Luan Nguyen ${ }^{\dagger \xi}$, Shiran Zhang ${ }^{\dagger \xi}$, Lei Wang ${ }^{\S}$, Yuanyuan $\mathrm{Li}^{\perp}$, Hideto Yoshida ${ }^{\nwarrow}$, Anitha Patlolla ${ }^{\perp}$, Seiji \\ Takeda", Anatoly I. Frenkel ${ }^{\perp}$, Franklin (Feng) Tao ${ }^{\xi *}$ \\ ${ }^{\xi}$ Department of Chemical and Petroleum Engineering and Department of Chemistry, \\ University of Kansas, Lawrence, KS 66045, USA \\ ${ }^{\S}$ Institute of Process Engineering, Chinese Academy of Sciences, Beijing 100190, China \\ ${ }^{\perp}$ Department of Physics, Yeshiva University, New York, NY 10016, USA \\ Institute of Scientific and Industrial Research, Osaka University, Osaka 567-0047, Japan
}

* To whom correspondence should be addressed. Email: franklin.feng.tao@ku.edu and frenkel@,bnl.gov

1. Ambient pressure X-ray photoelectron spectrometer and operando studies of surface chemistry of catalysts during catalysis
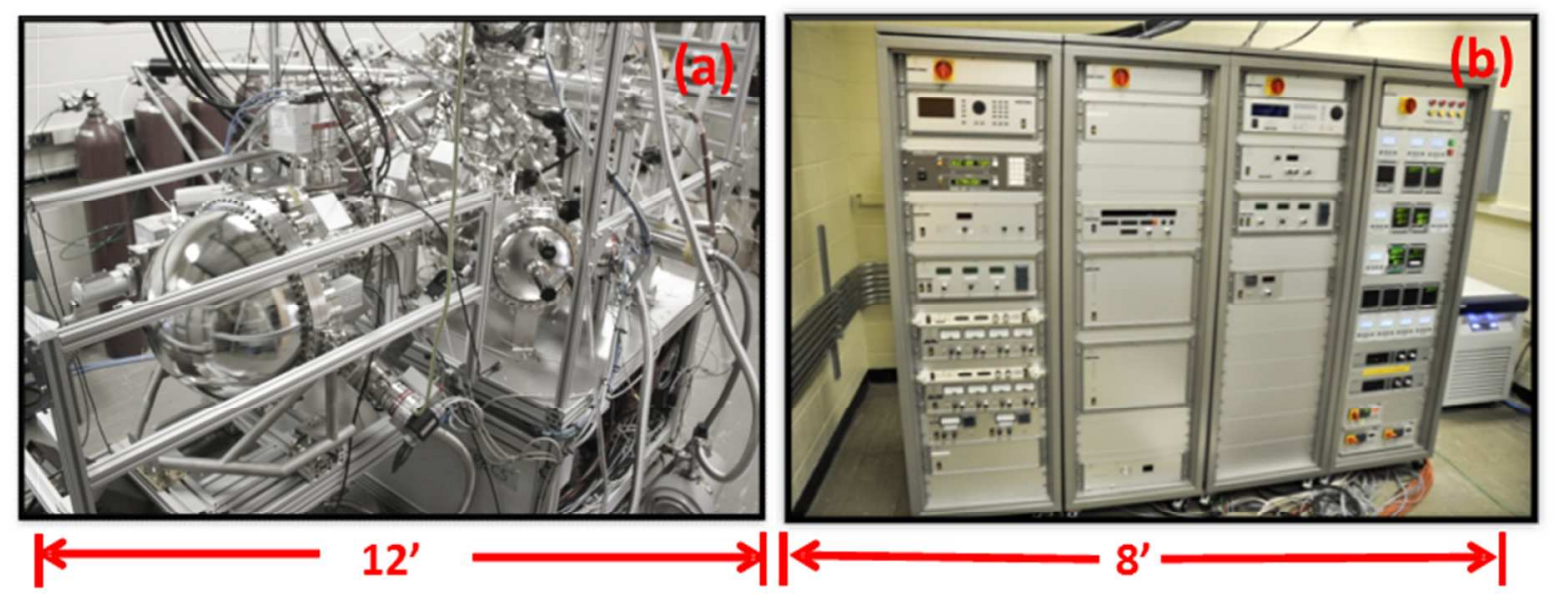

Figure S1 Photos of the ambient pressure XPS (AP-XPS) system in Tao group ${ }^{3}$. (a) In-house AP-XPS using monochromatic Al Ka; (b) Control system of the in-house AP-XPS in Tao group.

We used a lab-based AP-XPS with monochromatic Al Ka (Figure S1) available in Tao group. Figure S2 schematically shows the gas flow in the AP-XPS system for catalysis studies. Different from the static gas environment in the chamber-based AP-XPS, this system has a fixedbed flow reactor which was integrated with an X-ray source with high flux density and an ambient pressure energy analyzer. The introduced reactant gases flow through catalyst. Products 
and the left reactant gases are flowing out through an exit. The catalyst can be heated to different temperatures when the catalyst is in gaseous environments.

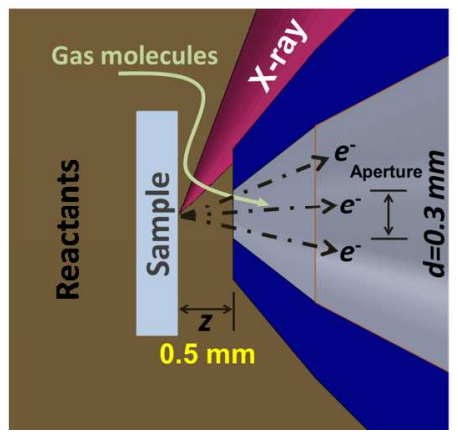

Figure S2 Schematic of the gas flow and main parts of an in-house ambient pressure X-ray photoelectron spectrometer.

2. Theoretical ratio of $\mathrm{Pt}$ to $\mathrm{Co}$ on surface of a $0.1 \mathrm{at} \% \mathrm{Pt} / \mathrm{Co}_{3} \mathrm{O}_{4}$ nanorod calculated under an assumption that all $\mathrm{Pt}$ atoms are exclusively dispersed on the surface of $\mathrm{Co}_{3} \mathrm{O}_{4}$ nanorods

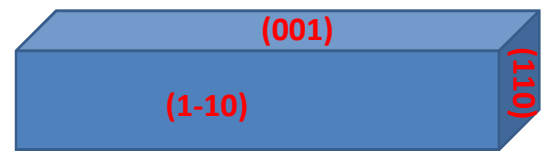

Figure $\mathrm{S3}$ Schematic of a $\mathrm{CO}_{3} \mathrm{O}_{4}$ nanorod $(6 \mathrm{~nm} \times 6 \mathrm{~nm} \times 100 \mathrm{~nm})$.

1) Volume of a nanorod $(6 \mathrm{~nm} \times 6 \mathrm{~nm} \times 100 \mathrm{~nm})$ : $V_{\mathrm{o}}=3,600 \mathrm{~nm}^{3}$

2) $\mathrm{N}_{\text {total }}(\mathrm{Co})=\rho_{\mathrm{Co}_{3} \mathrm{O}_{4}} \mathrm{~V}_{0} \times \frac{3 \mathrm{~N}_{\mathrm{A}}}{\mathrm{M}_{\mathrm{Co}_{3} \mathrm{O}_{4}}}, \rho_{\mathrm{Co}_{3} \mathrm{O}_{4}}=6.11 \mathrm{~g} / \mathrm{cm}^{3}$, $\mathrm{M}_{\mathrm{Co}_{3} \mathrm{O}_{4}}=240.8 \mathrm{~g} / \mathrm{mol}, \mathrm{N}_{\mathrm{A}}=6.02 \times 10^{23} / \mathrm{mol}$

$\mathrm{N}_{\text {total }}(\mathrm{Co})=164970$

3) Surface area of a nanorod $(6 \mathrm{~nm} \times 6 \mathrm{~nm} \times 100 \mathrm{~nm})($ see Figure $\mathrm{S} 3)$ :

Two (1-10) surfaces: $6 \mathrm{~nm} \times 100 \mathrm{~nm} \times 2=1200 \mathrm{~nm}^{2}$

Two (001) surfaces: $6 \mathrm{~nm} \times 100 \mathrm{~nm} \times 2=1200 \mathrm{~nm}^{2}$

Two (110) surfaces: $6 \mathrm{~nm} \times 6 \mathrm{~nm} \times 2=72 \mathrm{~nm}^{2}$

Total surface area of a nanorod: $2472 \mathrm{~nm}^{2}$ 


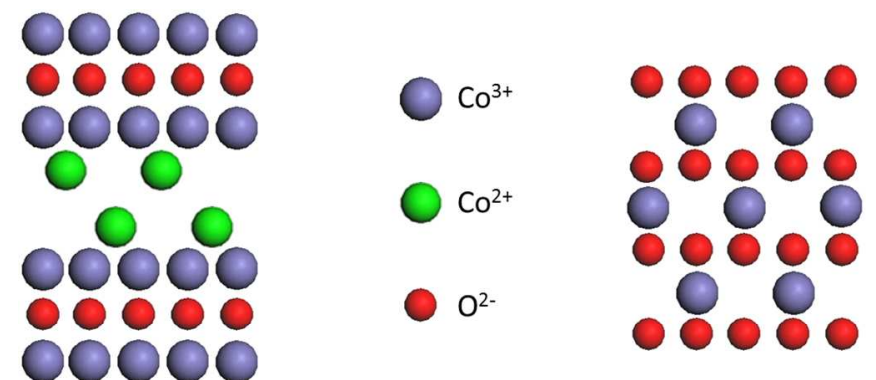

Type A

Type B

Figure S5 Schematic of types $A$ and $B$ surface of $\mathrm{Co}_{3} \mathrm{O}_{4}$ (1-10).

There are two kinds of terminations for $\mathrm{Co}_{3} \mathrm{O}_{4}$ (1-10): types $A$ and B. Type $A$ has both $\mathrm{Co}^{2+}$ and $\mathrm{Co}^{3+}$ while type $B$ has only $\mathrm{Co}^{3+}$ ions. We preferentially consider type $B$ as the exposed (110) surface of $\mathrm{Co}_{3} \mathrm{O}_{4}$ nanorods for catalysis since type $B$ surface of (1-10) exhibits high activity in $\mathrm{CO}$ oxidation resulting from a higher concentration of $\mathrm{Co}^{3+}$.

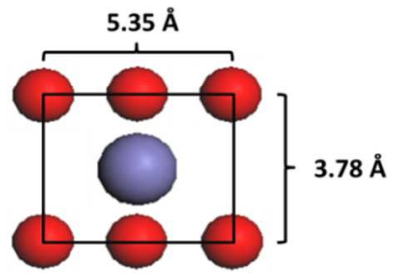

Crystal unit of Type B surface of (1-10) of $\mathrm{CO}_{3} \mathrm{O}_{4}$

$5 \mathrm{Co}^{3+} / 1 \mathrm{~nm}^{2}$

(a)

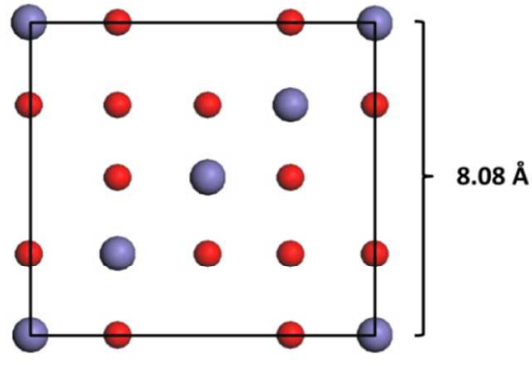

Crystal unit of (001) of $\mathrm{Co}_{3} \mathrm{O}_{4}$

$6.12 \mathrm{Co}^{3+} / 1 \mathrm{~nm}^{2}$

(b)

Figure S4 Surface structural parameters of type B surface of $\mathrm{CO}_{3} \mathrm{O}_{4}$ (1-10) (a) and $\mathrm{CO}_{3} \mathrm{O}_{4}(001)(b)$.

Figure S5 shows the size of a 2-D surface unit cell of type $\mathrm{B}$ surface of $\mathrm{Co}_{3} \mathrm{O}_{4}(1-10)$. For (1-10) and (001) surfaces, each square nanometer $\left(1 \mathrm{~nm}^{2}\right)$ has 5 ions and 6.12 ions of $\mathrm{Co}^{3+}$, respectively. So the number of $\mathrm{Co}^{3+}$ ions on a nanorod surface should be

$$
N\left(\mathrm{Co}^{3+}\right)=5 \times 1200+6.12 \times 1200+5 \times 72=13704 .
$$

That is, there are approximately $13704 \mathrm{Co}^{3+}$ ions on the surface of one $\mathrm{Co}_{3} \mathrm{O}_{4}$ nanorod, $\mathrm{N}_{\text {surface }}(\mathrm{Co})=13704$.

We know $\frac{\mathrm{N}(\mathrm{Pt})}{\mathrm{N}(\mathrm{Pt})+\mathrm{N}_{\text {total }}(\mathrm{Co})} \times 100 \%=0.1 \mathrm{at} \%$ based on ICP measurement.

Thus, $\mathrm{N}(\mathrm{Pt})=\mathrm{N}_{\text {total Co }} \times 0.1 \mathrm{at} \%=164970 \times 0.1 \mathrm{at} \%=165$ 
The theoretical ratio of all $\mathrm{Pt}$ atoms (assumed to be dispersed on the surface of $\mathrm{Co}_{3} \mathrm{O}_{4}$ nanorod) to all $\mathrm{Co}$ atoms of the topmost surface of $\mathrm{a}_{3} \mathrm{O}_{4}$ nanorod is

$\frac{\mathrm{N}(\mathrm{Pt})}{\mathrm{N}_{\text {surface }}(\mathrm{Co})}=\frac{165}{13704}=0.012=1.2 \%$

\section{Evolution of $\mathrm{Pt} 4 \mathrm{f}$ of singly dispersed $\mathrm{Pt}$ atoms on $0.5 \mathrm{at} \% \mathrm{Pt} / \mathrm{Co}_{3} \mathrm{O}_{4}$}

As Pt $4 \mathrm{f}$ overlaps with a small tail of Co $3 p$ (likely a satellite peak) ${ }^{15}$, contributions from Co $3 p$ should be subtracted. Photoemission intensity of Co $3 p$ including the tail at high binding energy side was obtained from AP-XPS study of a pure $\mathrm{Co}_{3} \mathrm{O}_{4}$ sample under the exactly same reaction conditions using the same acquisition parameters of AP-XPS experiments . Figure S6 is the Pt $4 \mathrm{f}$ upon subtraction of Co $3 p$ contribution. As marked with a red dashed line, peak of metallic $\mathrm{Pt}$ is at $71.2 \mathrm{eV}$. The photoemission feature of $\mathrm{Pt} 4 \mathrm{f}$ in $0.5 \mathrm{at} \% \mathrm{Pt} / \mathrm{Co}_{3} \mathrm{O}_{4}$ upon the subtraction of Co $3 p$ is at $73.8 \mathrm{eV}$ which is $2.6 \mathrm{eV}$ higher than metallic Pt. In fact, there is no photoemission feature at $71.2 \mathrm{eV}$ even if we don't subtract the contribution of Co $3 p$ tail. Figure S6 suggests that Pt atoms do not exist in the format of metal nanoclusters.

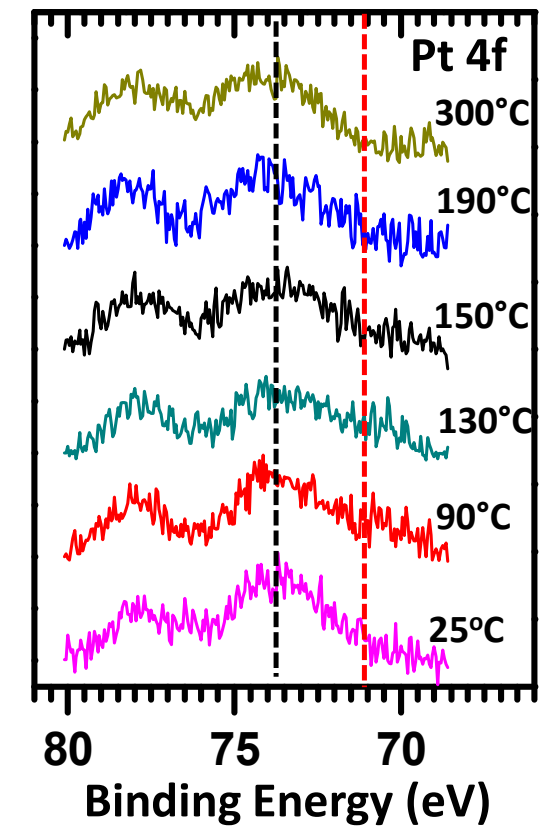

Figure S6 Pt 4 f of $0.5 a t \% ~ P t / \mathrm{CO}_{3} \mathrm{O}_{4}$ during catalysis in reduction of $\mathrm{NO}$ with $\mathrm{H}_{2}$ at different temperatures. 
4. AP-XPS studies of $0.5 \mathrm{at} \% \mathrm{Pt} / \mathrm{SiO}_{2}$ in $\mathrm{NO}+\mathrm{H}_{2}$

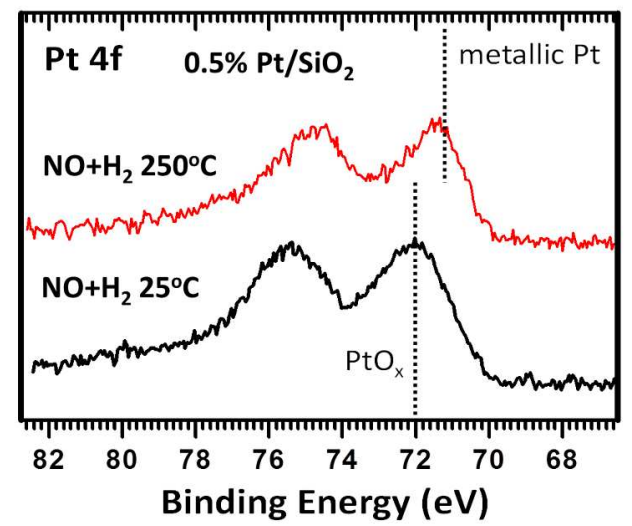

Figure S7 Pt $4 f$ photoemission feature of $0.5 a t \% \quad \mathrm{Pt} / \mathrm{SiO}_{2}$ at different temperature in a mixture of $\mathrm{NO}$ and $\mathrm{H}_{2}$.

5. XANES studies of $0.5 \mathrm{at} \% \mathrm{Pd} / \mathrm{Co}_{3} \mathrm{O}_{4}$ 


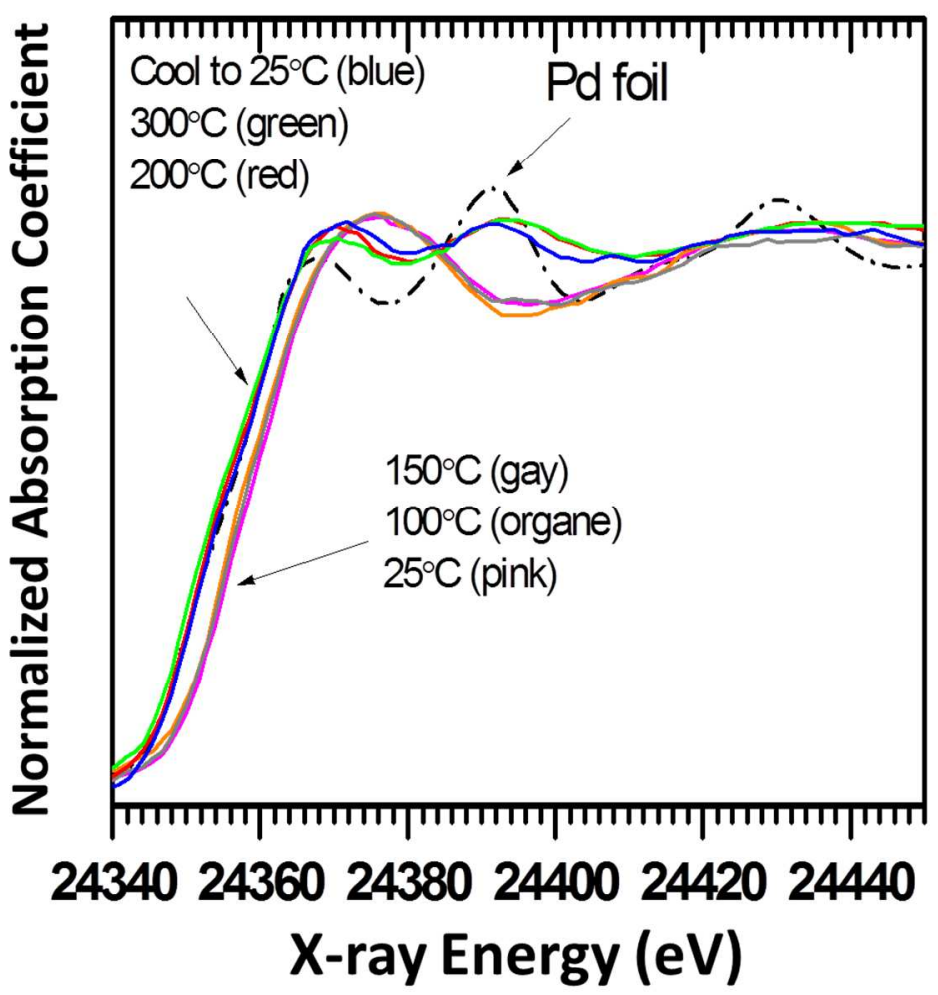

Figure S8. Pd K-edge XANES of $0.5 a t \%$ $\mathrm{Pd} / \mathrm{Co}_{3} \mathrm{O}_{4}$ catalyst during catalysis in the mixture of reactant gases in the temperature regime of $25^{\circ} \mathrm{C}-300^{\circ} \mathrm{C}$. K edge of metallic $\mathrm{Pd}$ foil was included for a comparison.

The preservation of oxidation state of $\mathrm{Pd}$ at different temperatures is also supported by XANES studies. Oxidation state of $\mathrm{Pd}$ atoms on $\mathrm{Co}_{3} \mathrm{O}_{4}$ surface was investigated with $\mathrm{Pd} \mathrm{K}$-edge XANES. Figure S8 presents the Pd K-edge XANES data of 0.5 at $\% \mathrm{Pd} / \mathrm{Co}_{3} \mathrm{O}_{4}$ during catalysis. K-edge of metallic Pd foil was included in Figure S8 for a comparison. The cationic state of palladium in the as-synthesized catalyst and the active catalyst during catalysis up to $300^{\circ} \mathrm{C}$ is clearly different from that of metallic Pd foil. For catalyst at $25^{\circ} \mathrm{C}, 100^{\circ} \mathrm{C}$ and $150^{\circ} \mathrm{C}$, they exhibit a very similar chemical state. However, absorption edges at $200^{\circ} \mathrm{C}$ and $300^{\circ} \mathrm{C}$ have downshifted in contrast to those at a temperature $\leq 150^{\circ} \mathrm{C}$. This is consistent with the downshift of $\mathrm{Pd} 3 \mathrm{~d}$ photoemission peak in AP-XPS when catalyst is heated to $200^{\circ} \mathrm{C}$ from $100^{\circ} \mathrm{C}$ (Figures $13 \mathrm{~b} 1$ and $13 \mathrm{~b} 2$ in main text). K-edge feature remains almost the same in the temperature regime of $200^{\circ} \mathrm{C}$ $300^{\circ} \mathrm{C}$.

The absorption edge of Pd during catalysis at $200^{\circ} \mathrm{C}-300^{\circ} \mathrm{C}$ identified with XANES is different from that of metallic Pd foil (Figure S8). It shows Pd atoms in the temperature regime of $200^{\circ} \mathrm{C}-300^{\circ} \mathrm{C}$ do not aggregate to form metallic $\mathrm{Pd}$ nanoparticles. This is consistent with the high binding energy $(337.6 \mathrm{eV})$ of $\mathrm{Pd} 3 \mathrm{~d}$ during catalysis at $200^{\circ} \mathrm{C}-300^{\circ} \mathrm{C}$ identified with APXPS which is about $2.5 \mathrm{eV}$ higher than metallic Pd.

6. Comparison of $\mathrm{N}_{2}$ selectivities of $0.5 \mathrm{at} \% \mathrm{Pt} / \mathrm{Co}_{3} \mathrm{O}_{4}$, pure $\mathrm{Co}_{3} \mathrm{O}_{4}$, and $0.5 a t \% \mathrm{Pt} / \mathrm{SiO}_{2}$ at similar conversions of NO 
$100 \mathrm{mg}$ of $0.5 \mathrm{at} \% \mathrm{Pt} / \mathrm{Co}_{3} \mathrm{O}_{4}, 250 \mathrm{mg}$ of pure $\mathrm{Co}_{3} \mathrm{O}_{4}$, and $200 \mathrm{mg}$ of $0.5 \mathrm{at} \% \mathrm{Pt} / \mathrm{SiO}_{2}$ were measured under the same catalytic conditions of $\mathrm{NO}+\mathrm{H}_{2}$ in order to obtain similar conversions of

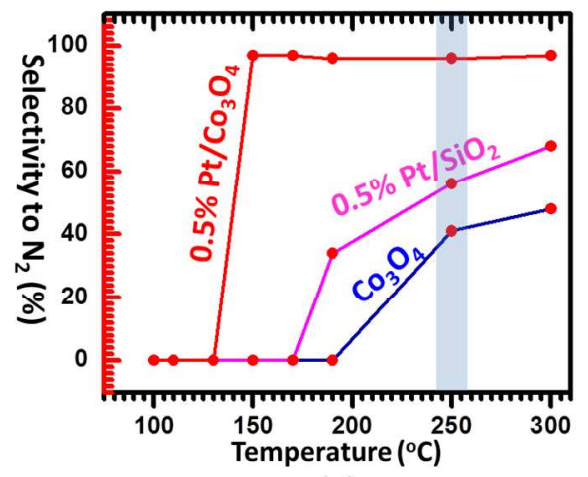

(a)

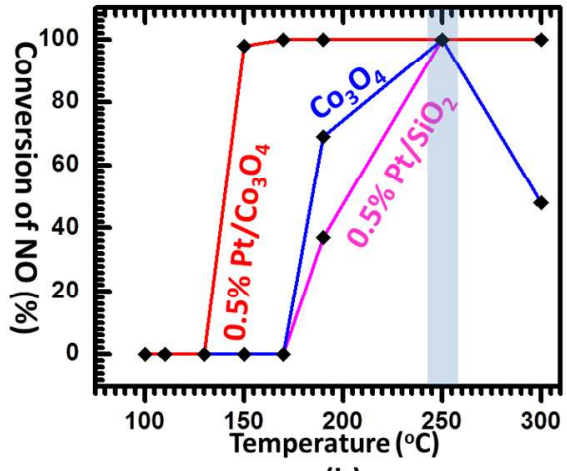

(b)

Figure S9. Comparison of (a) catalytic selectivities and (b) catalytic activities of $100 \mathrm{mg}$ of $0.5 \mathrm{at} \% \mathrm{Pt} / \mathrm{Co}_{3} \mathrm{O}_{4}, 250 \mathrm{mg}$ of pure $\mathrm{Co}_{3} \mathrm{O}_{4}$, and 200 $m g$ of $0.5 \mathrm{at} \% \mathrm{Pt} / \mathrm{SiO}_{2}$ under the same catalytic conditions.

$\mathrm{NO}$ at the same temperature. Catalytic performances of these catalysts under the same catalytic condition were presented in Figure S9. At $250{ }^{\circ} \mathrm{C}$ conversions of $\mathrm{NO}$ of these three catalysts all reach $98 \%$. Selectivities for production of $\mathrm{N}_{2}$ on pure $\mathrm{Co}_{3} \mathrm{O}_{4}$ and $0.5 \mathrm{at} \% \mathrm{Pt} / \mathrm{SiO}_{2}$ are still significantly lower than $0.5 \mathrm{at} \% \mathrm{Pt} / \mathrm{Co}_{3} \mathrm{O}_{4}$.

\section{Comparison of catalytic performances of $0.5 \mathrm{at} \% \mathrm{Pd} / \mathrm{Co}_{3} \mathrm{O}_{4}$ in the first-run and second-run}

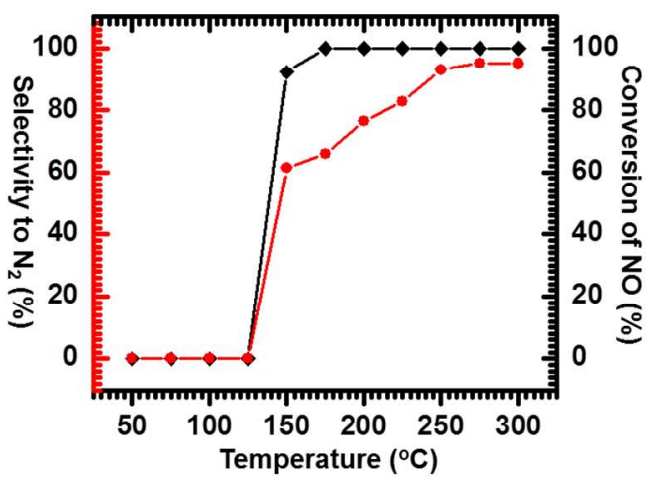

(a)

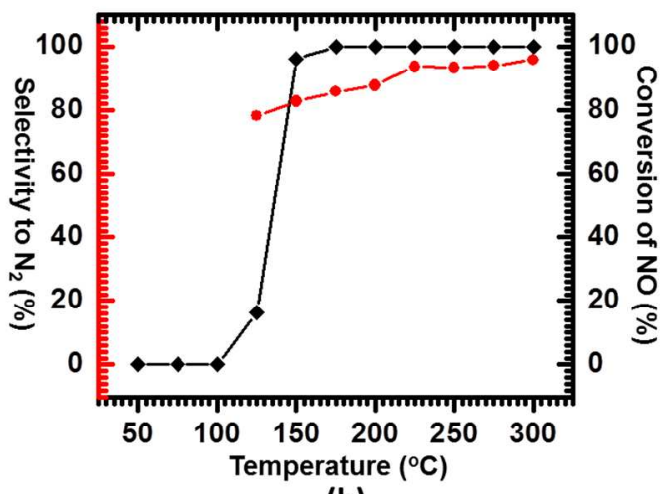

(b)

Figure S10. Catalytic performances of $0.5 \mathrm{at} \% \mathrm{Pd} / \mathrm{Co}_{3} \mathrm{O}_{4}$ in (a) first-run, and (b) secondrun cooled from $300^{\circ} \mathrm{C}$ in the mixture of $\mathrm{NO}$ and $\mathrm{H}_{2}$, measured under the same catalytic conditions. Red: selectivity for production of $\mathrm{N}_{2}$. Black: conversion of NO. 


\section{References}

(1) Lindberg, B.; Asplund, L.; Fellnerfeldegg, H.; Kelfve, P.; Siegbahn, H.; Siegbahn, K. Chem. Phys. Lett. 1976, 39, 8.

(2) Joyner, R. W.; Roberts, M. W.; Yates, K. Surf. Sci. 1979, 87, 501.

(3) Tao, F. Chem. Commun. 2012, 48, 3812.

(4) Ogletree, D. F.; Bluhm, H.; Lebedev, G.; Fadley, C. S.; Hussain, Z.; Salmeron, M. Rev. Sci. Instrum. 2002, 73, 3872.

(5) Bluhm, H.; Haevecker, M.; Knop-Gericke, A.; Kiskinova, M.; Schloegl, R.; Salmeron, M. MRS Bull. 2007, 32, 1022.

(6) Knop-Gericke, A.; Kleimenov, E.; Haevecker, M.; Blume, R.; Teschner, D.; Zafeiratos, S.; Schloegl, R.; Bukhtiyarov, V. I.; Kaichev, V. V.; Prosvirin, I. P.; Nizovskii, A. I.; Bluhm, H.; Barinov, A.; Dudin, P.; Kiskinova, M. In Advances in Catalysis, Vol 52; Gates, B. C. K. H., Ed. 2009; Vol. 52, p 213.

(7) Teschner, D.; Pestryakov, A.; Kleimenov, E.; Havecker, M.; Bluhm, H.; Sauer, H.; KnopGericke, A.; Schlogl, R. J. Catal. 2005, 230, 186.

(8) Grass, M. E.; Karlsson, P. G.; Aksoy, F.; Lundqvist, M.; Wannberg, B.; Mun, B. S.; Hussain, Z.; Liu, Z. Rev. Sci. Instrum. 2010, 81.

(9) Powell, C. J. J., A. NIST Electron Inelastic Mean Free Path Database; 1.2 ed.; National Institute of Standards and Technology, Gaithersburg, MD, 2010.

(10) Seah, M. P.; Spencer, S. J. Surf. Interface Anal. 2002, 33, 640.

(11) Hesse, R.; Streubel, P.; Szargan, R. Surf. Interface Anal. 2005, 37, 589.

(12) Jablonski, A.; Zemek, J. Surf. Interface Anal. 2009, 41, 193.

(13) Kannan, R.; Seehra, M. S. Phys. Rev. B 1987, 35, 6847. 2008, 20 .

(14) Meyer, W.; Biedermann, K.; Gubo, M.; Hammer, L.; Heinz, K. J. Phys., Condens. Matter

(15) Moulder, J. F. S., W. F.; Sobol, P. E.; Bomben, K. D. Handbook of X-ray Photoelectron Spectroscopy; Perkin-Elmer Corporation: Minnesota, 1992. 